\title{
Environmental health behavior of fishing communities during COVID-19 pandemic
}

\author{
Singgih Susilo*, Budijanto \& Ifan Deffinika \\ Universitas Negeri Malang, Malang, Indonesia
}

\begin{abstract}
The chaotic settlement environmental problems, causing slum environments to be scattered in various corners of the area. This study aims to find and reveal the various conditions behind the low environmental health behavior of fishing communities in facing the COVID-19 Pandemic. This study used a quantitative descriptive approach. The population in this study were housewives who had toddlers in Pamekasan Regency fishing community, and the sample was taken purposively using in-depth interviews to gather information. The research results show that the environmental health behavior of the fishing community is in a good category. Most of them use clean water from PDAM and have a special place for disposal. The handling of the COVID-19 Pandemic in this community is in the low category. But even so, none of the fishing communities have been exposed to COVID-19, even though Pamekasan Regency is in the red zone.
\end{abstract}

\section{INTRODUCTION}

The quality of life of a nation among others can be measured from the death rate. Many nations have achieved low mortality rates which generally have a relatively high socio-economic level. Through improving public health, it can be expected that the survival rate of children will be higher. Evidence shows that in developed countries more than $97 \%$ of children can survive to the age of five, while in developing countries 20 to $25 \%$ of babies born die before reaching the age of five (Mosley 1984). The results of preliminary observations at the research location show that there are factors that continue to encourage the low environmental health of fishing community settlements, namely limited environmental health infrastructure and low education which results in low access to job opportunities supported by unfavorable demographic characteristics. Thus causing the low environmental hygiene in the fishing community.

The relationship between socio-economic factors and mortality cannot be direct, but must go through intermediate variables. According to Mosley and Chen (1984), the relationship be-tween these two variables will be through an intermediate variable consisting of factors related to motherhood, environmental pollution, malnutrition, and individual illness monitoring. This phenomenon occurs in the community living in the fishing community in the village of Branta Tinggi. So on this occasion, the researcher' want to conduct research in relation to the most basic problems, namely environmental health problems. The topic raised in this research is: Environmental Health Behavior of Fishing Communities Settlements in Branta Tinggi Village, Tlanakan District, Pamekasan Regency.

This study intends to reveal the behavior conditions of the fishing community during the COVID-19 Pandemic in Branta Tinggi Village, Tlanakan District, Pamekasan Regency. With the socio-cultural characteristics that exist in the community, the results of this study will later become a reference for determining solutions for parties related to handling COVID-19 in the regions.

\footnotetext{
*Corresponding author: singgih.susilo.fis@um.ac.id
} 


\section{METHOD}

This study was designed with an "explanatory research and research and development" approach. This approach explains the symptoms caused by an object of research, namely the influence of socio-economic and demographic backgrounds on environmental health behavior during the COVID-19 Pandemic in the fishing community of Branta Tinggi Village. The quantitative approach is based on deductive and "inductive" theories relying on "natural" data from the field to find environmental health behaviors and health behaviors for the COVID-19 Pandemic that are applicable to fishing communities.

To determine the research location and program targets are based on: The health behavior of the fishing community in Pamekasan Regency. This area is one of the areas located in the Port Area II, Branta Tinggi Village, Tlanakan District, Pamengkasan Regency where there are fish-ing community settlements. Therefore, the selection of this area was carried out purposively with the determination of non-random research areas (non-probability sampling) which selected based on certain considerations (Singarimbun 1989).

The number of the samples taken was 300 respondents who were divided into three hamlets namely Dusun Tengah, Dusun Gedungan and Dusun Planggaran. The first thing to do to selecting the respondents is population enumeration at the location of household with children under five in the study area. Second, the researcher determined the number of samples at each specified location. Third, determine the amount of the interval done by dividing the population in each location by the number of samples 1 . Then, each interval is taken by the respondent randomly. For example, the interval size (1) is 10. If in random to determine sample 1, the first respondent is selected number 5 . If the selected sample doesn't meet the requirements or it isn't available, then it is replaced with the closest respondent.

The data analysis in this study was carried out using quantitative and qualitative techniques. Quantitative data were analyzed using percentage and statistical tables. To capture the information and data researcher find out about the study area condition which carried out by using maps. The household (that have children under five) characteristic information was obtained by using non-participation observation, documentation study, participatory observation, and interview.

\section{RESULT AND DISCUSSION}

The location of this research is in the coastal area of Pamekasan Regency, more precisely is in port area III in Pamekasan Regency which is quite far (about $8 \mathrm{~km}$ ) from the health center (located close to the Tlanakan District health center). According to the researchers' observations, the location is a port area so that areas with relatively low elevations are always inundated by seawater and the water is relatively black, dirty and stinks. Apart from that, the results of the researcher observations and interviews with the community stated that the sanitation and environment office rarely and almost never conducts field visits to this area. The results showed that the low number of health behaviors in an area was due to behavioral factors.

\subsection{Disposal place}

Garbage Disposal Place is a facility used in everyday life related to waste generated from activities in one day. The use of these facilities reflects the management of the health behavior of each household. Prawiro (1988: 69) states that in cities it is increasingly difficult to find disposal sites and there are more waste materials, so the beach becomes an alternative as a place to dispose of waste/feces as well as being the main source for meeting water needs.

As shown in Table 1, 71.1\% of the respondents already have a special place for garbage disposal. The facilities are made of rubber tires, cement (in a form of small tub), cans (in the form of small drums), woven bamboo (simpler, in the form of baskets) and others. This community group can be interpreted as having good health behavior management. They are fully aware that waste which 
Table 1. Component of environmental health behavior of Pamekasan Regency Fishing Community.

\begin{tabular}{|c|c|c|c|c|c|c|c|}
\hline \multicolumn{4}{|c|}{ A. Disposal place } & \multicolumn{4}{|c|}{ C. Sanitary Place } \\
\hline No & Place & $\mathrm{f}$ & $\%$ & No & Place & $\mathrm{f}$ & $\%$ \\
\hline 1 & Beach & 51 & 24.30 & 1 & Beach & 46 & 15.30 \\
\hline 2 & Water gutter & 37 & 12.33 & 2 & Public sanitary & 89 & 29.70 \\
\hline 3 & Special place & 212 & 71.70 & 3 & Private sanitary & 165 & 55.00 \\
\hline \multicolumn{4}{|c|}{ B. Household waste disposal sites } & \multicolumn{4}{|c|}{ D. Clean water } \\
\hline No & Place & $\mathrm{f}$ & $\%$ & No & Water resource & $\mathrm{f}$ & $\%$ \\
\hline 1 & Beach & 62 & 20.70 & 1 & Water well & 106 & 35.40 \\
\hline 2 & Open drains & 182 & 61.60 & 2 & PDAM & 194 & 64.60 \\
\hline 3 & Special place & 56 & 18.70 & & & & \\
\hline
\end{tabular}

consists of waste products affects the health of the population. But there are still $29.3 \%$ who use the beach $(24.3 \%)$ and water gutter $(5.0 \%)$ as their disposal place.

\subsection{Household waste disposal sites}

The place to dispose of household waste is a facility used in everyday life related to the waste that is generated by daily activities in the household in the form of liquid objects from washing kitchen utensils after cooking or washing clothes and so on. The use of these facilities reflects how the health behavior of each household. Household waste disposal sites are divided into three criteria, namely open channel beaches and special places.

Based on the Table 1, it shows that $61.6 \%$ of the population of waste water disposal sites generally use an open drain to a ditch, so that creates an unfavorable and dirty view. It also causes unpleasant odors and disturbs comfort. If this condition is left for a relatively long time, it will cause various kinds of diseases and unhealthy environment. Only $18.7 \%$ of households have a specific household waste disposal site, in the form of infiltration wells with a depth of about $10 \mathrm{~m}$ above it and cast cement with a hole in the form of a pipe, such as a septic tank. The low percentage of this household group caused by the distance between the houses is too close. Resulting in no more usable land for the waste disposal absorption wells. This household group can be interpreted as having good health behavior management. They are very aware and understand that household waste which consists of waste products can affects environmental health.

\subsection{Sanitary place}

Place for defecation or sanitary (for bathing and washing) is a facility used in everyday life. The use of these facilities reflects the management of the health behavior of each household. Based on the Table $1,55.0 \%$ of the population already has their own toilet. In daily life, the disposal of feces generally uses a goose neck toilet $(100 \%)$. From the percentage, it can be concluded that the temporary findings of the majority of the community have understood the importance of health shown in managing good health behavior for family members in their household.

On the other hand, there are still $15.3 \%$ who use the beach as a toilet. It shows that there are still people who don't understand the importance of environmental health management. This group is those who do not own any sanitary and use public toilets that sometimes together with members of other societies. However, the results of investigations by researchers through in-depth interviews from this group were not only for the toilet, not including bathing and washing. 
Table 2. Class of environmental health behavior of Pamekasan regency fishing community.

\begin{tabular}{llll}
\hline No & Environmental & & $\%$ \\
\hline 1 & Health Behavior & f & 15.67 \\
2 & Less & 47 & 32.00 \\
3 & Moderate & 96 & 52.33 \\
\hline
\end{tabular}

\subsection{Clean water}

The source of clean water is water that is consumed for daily living needs includes eating, drinking, bathing, and washing. The description of the source of clean water used is divided into two sources, namely PDAM and water wells. Furthermore, from the two sources of clean water, the western part of the Pamekasan Sumenep road mostly uses PDAM, be-cause the salty water that this area (which is located in the coastal area) have. Meanwhile, the eastern one, Jalan Raya uses a well. They're using the water well because the water tasteless.

Based on the Table 1, it shows that $64.6 \%$ of the population has used PDAM as a source of clean water for their daily lives. They assume that PDAM is undoubted because it meets health standards for consumption. But, the people who use wells as a source of clean water are still quite high at $35.4 \%$. Based on the results of the study, it was found that most people use water wells as a source of drinking water (42\%) and in terms of requirements most of them have met the health requirements, namely construction $(85.72 \%)$ and depth $(100 \%)$, most of which have used sanyo. On the other hand, there are still $9.7 \%$ who use the beach as a source of clean water.

Most people in this community have a good health behavior management related to the use of clean water. In accordance with the statement of Iskandar (2013: 83), people who live along the coast tend to use dirty beach water for daily purposes. However, the results of the researchers' tracing through in-depth interviews from this group were only for bathing and washing. For the purpose of eating and drinking there were some who took water from their neighbors' wells, and there were also those who said they took from springs around/on either side of the beach.

\subsection{Environmental health behavior}

Environmental Health Behavior is a phenomenon that shows how the environmental health behavior in settlements by people in these settlements. The health behavior of the residential environment shows the daily phenomenon of how to consume clean water sources, dispose of feces, dispose of garbage, and dispose of household waste. The results showed that environmental health behavior in the community is as in the Table 2:

Based on the Table 2 above, we can see that $52.33 \%$ of the population has good management of environmental health behavior. $32 \%$ of the fishing community is categorized as moderate and $15.67 \%$ is categorized as less in the management of environmental health behavior. This finding needs to be criticized because this shows that there are still community groups who have bad environmental health behavior management and do not fully understand the meaning of healthy life. The use and consumption (for eating and drinking) of water, the garbage which is left for a few days (besides causing an unpleasant odor it is also unpleasant, especially in sensitive community groups like toddlers), and the disposal of feces and household waste, it all causes bad environmental health behavior. But even so, it can be concluded that most people in the fishing community of Pamekasan Regency understand the importance of environmental health. It is shown in how they managing good health behavior for their family members in the household. 


\section{CONCLUSION}

The health behavior of the COVID-19 pandemic apart from being related to maternal education, family income and dependency, is also related to health behavior, especially with regard to the use of clean water resources. The community tends to use springs on either side of the beach which have a large potential for having contaminated water. On the beach, we can still see waste disposals (or even household disposals) that dispose into the open drains or directly to the beach. In addition, we can see in the use of public toilets that there are also those who use the beach as a toilet.

There needs to be a high priority scale especially for community groups who still do not know good and correct health behavior, especially during the pandemic like now. There is a need for concrete steps to provide an understanding of the impact on coastal users, especially by the mjority of the population downstream.

\section{REFERENCES}

Agence Française de Développement (2020) Resources for Managing Water \& Sanitation During the Coronavirus Pandemic, Institutional Document. Available at: https://www.afd.fr/en/ressources/resourcesmanaging-water-sanitation- during-coronavirus-pandemic.

Ahyanti, M. (2020) 'Sanitasi Pemukiman pada Masyarakat dengan Riwayat Penyakit Berbasis Lingkungan Sanitation of Community Settlements with a History of Environmental- Based Diseases', Jurnal Kesehatan Poltekkes Tanjungkarang.

Atmadja, S. S. et al. (2017) 'Explaining environmental health behaviors: Evidence from rural India on the influence of discount rates', Environment and Development Economics. doi: 10.1017/S1355770X17000018.

BBC Indonesia (2020) Virus Corona: Tops Terlindungi dari COVID-19 dan Mencegah Penyebaran Sesuai Petunjuk WHO, BBC News. Available at: https://www.bbc.com/indonesia/dunia-52127080.

BPS (2020) Hasil Survei Sosial Demografi Dampak COVID-19 2020, Jakarta: Badan Pusat Statistik. Available at: https://www.bps.go. id/publication/2020/06/01/669cb2e8646787e52dd171c4/hasil-survei-sosialdemografi-dampak-COVID-19-2020.html.

BPS Kabupaten Pamengkasan (2020) Hasil Survei Sosial Demografi Dampak COVID-19Via Daring Terbaru, Kabupaten Pamengkasan: Badan Pusat Statistik.

Butler, G., Pilotto, R. G. and Hong, Y., and Mutambatsere, E. (2020) The Impact of COVID-19 on the Water and Sanitation Sector, International Finance Corporation. Available at: https://www.ifc.org/wps/wcm/ connect/126bla18-23d9-46f3-beb7-047c20885bf6/ The+Impact+of+COVID_Water\%26Sanitation_final_ web.pdf?MOD=AJPERES\&CVID=ncaG-hA.

Cooper, R. (2020) Water Security Beyond COVID-19, K4D. Available at: https://reliefweb.int/sites/reliefweb. int/files/resources/803_Water_security_beyond_C19.pdf.

FAO (2020) Building Water Access for a COVID-19 Response: Multiple Water Use Systems, Water Stations, Airto-Water Non-Conventional Technologies (Enhancing Access to Clean Water in Response to COVID-19), Land \& Water. Available at: http://www.fao.org/land-water/overview/covid19/access/en/.

Hermana, J. (2020) Aspek Pengelolaan Infrastruktur Sanitasi Pasca COVID-19, kkp.go.id. Available at: https://kkp.go.id/an-component/media/upload-gambar- pendukung/DitJaskel/publikasi-materi-2/penataanwilayah/Materi 2 - Presentasi JH Webinar 18 Juni.pdf.

Iskandar, Z. (2013) Psikologi Lingkungan: Metode dan Aplikasi. Bandung: Refika Aditama.

Kementerian PUPR (2020) Perilaku Hidup Bersih dan Sehat (PHBS) sebagai Upaya Mencegah Penyebaran COVID-19, Portal IBM Sanitasi. Available at: http://plpbm.pu.go.id/v2/posts/Perilaku-Hidup-Bersih-danSehat-PHBS- sebagai-Upaya-Mencegah-Penyebaran-COVID-19.

Khairani, A. I. (2016) 'Sanitasi Lingkungan Rumah dan Sosial Budaya Masyarakat Pesisir Pantai Terhadap Ke-jadian Skabies', Jurnal Riset Hesti Medan, 1(1). Available at: https://doi.org/10.34008/jurhesti.v1i1.7.

Moslley and Chen (1984) Child Survival: Strategies for Research. Cambridge: University Press.

Munir, R., Utomo, B. and Sutrisno (1992) Morbiditas dan Mortalitas di Indonesia: Suatu penelitian di enam desa di Yogyakarta dan Lombok. 1990 LD-FEUI.

Nursiah, A. et al. (2016) 'Environment Sanitation and Patterns of Disease in Coastal Community at Langnga Mat-tirosompe Village Pinrang Regency 2015', International Journal of Applied Environmental Sciences, 11(4), pp. 927-640.

Prawiro, R. H. (1988) Ekologi Lingkungan Pencemaran. Semarang: Satyawacana. 
Purnamasari, I. and Rahayani, A. (2019) 'Preventive Health Behaviors of Community During COVID-19 Pandemic: A Descriptive Study', Indonesian Journal of Global Health Research, 2(4), pp. 301-308. doi: 10.37287/ijghr.v2i4.232.

Putra, Y. and Wulandari, S. S. (2019) 'FAKTOR PENYEBAB KEJADIAN ISPA', Jurnal Kesehatan. doi: $10.35730 / \mathrm{jk} . v 10 \mathrm{i} 1.378$.

Saleh, M. and Rachim, L. H. (2014) 'Hubungan Kondisi Sanitasi Lingkungan dengan Kejadian Diare pada Anak Balita di Wilayah Kerja Puskesmas Baranti Kabupaten Sidrap Tahun 2013', Jurnal Kesehatan.

Satgas COVID-19 (2020) Cara Melindungi Diri Terhadap virus Corona (COVID-19). Konten Berguna. Available at: https://covid19.go.id/p/konten/cara-melindungi-diri-terhadap-virus- corona-COVID-19.

Sumertha Gapar, I. G., Adiputra, N. and Pujaastawa, I. B. G. (2015) 'HUBUNGAN KUALITAS SANITASI RUMAH DENGAN KEJADIAN PENYAKIT INFEKSI SALURAN PERNAPASAN AKUT (ISPA) DI WILAYAH KERJA PUSKESMAS IV DENPASAR SELATAN KOTA DENPASAR', ECOTROPHIC?: Jurnal Ilmu Lingkungan (Journal of Environmental Science). doi: 10.24843/ejes.2015.v09.i02.p07.

Unicef (2020) To Beat COVID-19, Hand Hygiene Must Become an Everyday Reality for All Indonesian, Press Release. Available at: https://www.unicef.org/indonesia/press-releases/beat-COVID-19-handhygiene-must-become-everyday-reality-all-indonesians.

World Health Organization (2020) WHO Coronavirus Disease (COVID-19) Dashboard. Available at: https://covid19.who.int/.

World Health Organization (2020) Air, Sanitasi, Higine, dan Pengelolaan Limbah yang Tepat Dalam Penanganan Wabah COVID-19, Pedoman Sementara WHO dan UNICEF. Available at: https://www.who.int/docs/default-source/searo/indonesia/covid19/who-unicef-air-sanitasi-higiene-danpengelolaan-limbah-yang-tepat-dalam-penanganan-wabah-COVID-19.pdf?sfvrsn=bf12a730_2.

Yoada, R. M., Chirawurah, D. and Adongo, P. B. (2014) 'Domestic waste disposal practice and perceptions of private sector waste management in urban Accra', BMC Public Health. doi: 10.1186/1471-2458-14-697. 